
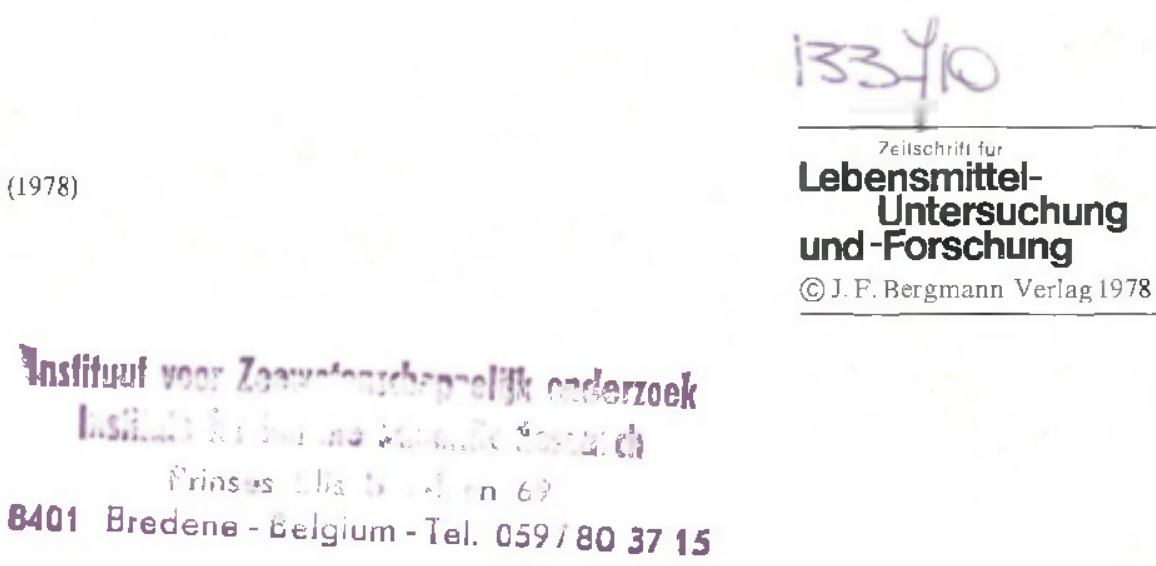

\title{
Influence of Sodium Tripolyphosphate and Citric Acid on the Shelf Life of Thornback Ray (Raja clavata L.)
}

\author{
Wilfried Vyncke \\ Ministry of Agriculture, Fisheries Research Station, Ankerstraat 1, B-8400 Oostende, Belgium
}

\section{Einfluß von Natriumtripolyphosphat und Citronensäure auf die Haltbarkeit von Nagelrochen (Raja clavata L.)}

Zusammenfassung. Das Eintauchen von Nagelrochenflïgeln in Natriumtripolyphosphatlösung (12\%) während 5 min verlängerte die Haltbarkeitsdauer mit etwa 2 Tagen, verhesserte das Aussehen und schaltete Gewichtsverluste aus. Mit Citronensäure ( 5 min in 0,5\% Lösung) wurde eine Verbesserung der Haltbarkeit von ungefähr 3 Tagen bekommen, aber diese Behandlung verursachte ein leichtes Ausbleichen und Gewichtsverluste von etwa $5 \%$.

Beide Verbindungen konnten zweckmäßig das Abbauen des Harnstoffes zu Ammoniak in Nagelrochen verzögern

Summary. Sodium tripolyphosphate dips $(5 \mathrm{~min}$ in $12 \%$ solution) extended shelf life of thornback ray wings by about 2 days, improved the appearance and eliminated weight losses. With citric acid dips ( $5 \mathrm{~min}$ in $0.5 \%$ solution) a 3 day extension of storage life was obtained but the treatment had a slight bleaching effect and caused weight losses of about $5 \%$. Both compounds were effective in retarding the breakdown of urea with formation of ammonia in thornback ray.

The formation of ammonia caused by the breakdown of the urea abundantly present in the muscle, blood and organs of elasmobranch fish such as ray, skate and dogfish is often a problem in the fish trade. In a previous paper [1] the development of ammonia in thornback ray (Raja clavata L.) was studied. This fish appeared to be on the borderline of acceptability at a concentration of $60-70 \mathrm{mg}$ ammonia- $\mathrm{N}$ per $100 \mathrm{~g}$.

Attempts were further made to inhibit the often rapid formation of ammonia and to increase the shelfIife of this cartilaginous fish. This paper reports results obtained with sodium tripolyphosphate (TPP) and citric acid dips.

The water holding capacity of polyphosphates is well known, and these compounds are used in several countries mainly to reduce drip of frozen seafood. Polyphosphates were also reported to show antioxidant and bacteriostatic or bactericidal properties in several commodities including fish [2-6].

Citric acid is widely used in the food industries especially for its preservative action due to $\mathrm{pH}$ lowering and its synergetic effect for antinxidants due to its metal-chelating action. It is used in cured, canned and frozen fishery products $[7,8]$. As far as elasmobranch fish are concerned, mention should be made of shark species which are often soaked in a dilute citric acid solution to remove a large part of the urea and ammonia present in the muscle prior to salting and drying or smoking $[9,10]$. Some forty years ago, citric acid was also tested to a very limited extent on fresh fish fillets in Canada. A significant prolongation of the shelf life of several flatfish species was reported when using $1.5-1.8 \%$ dips, but the fish lost $20-30 \%$ of weight during storage owing to excessive drip $[11,12]$.

To the author's knowledge, no results have been reported on the use of citric acid on fresh rays or other cartilaginous fish.

\section{Materials and Methods}

Fish

Thornback rays from the Southern North Sea weighing $2.5-3.5 \mathrm{~kg}$ and $4( \pm 1)$ days old at landing were dressed on the premises of a wholesale trader by severing the wings from the trunk and skinning them.

Somewhat older rays were taken than for the previous experiments in order to adhere more closely to actual commercial realities.

Laboratory Methods

Ammonia, $\mathrm{pH}$, total bacterial counts and organoleptic scores (intensity of the odour of ammonia determined on raw, steamed and 



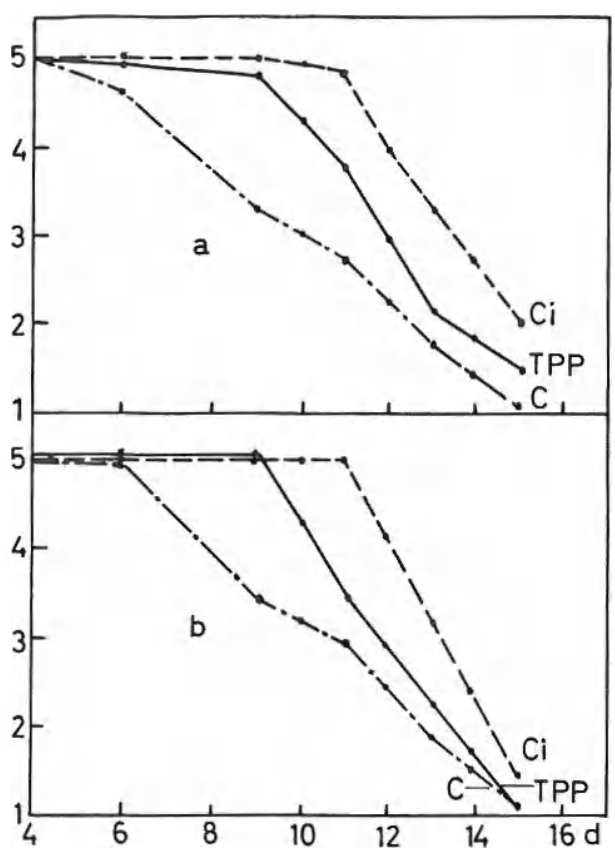

Fig. 1 a and b. Evolutinn of organoleptic scores of raw a and steamed b rays during storage in ice ( $\mathrm{Ci}$ : dipped in $0.5 \%$ citric acid; IPP: dipped in sodium tripolyphosphate $12 \%$; C: control sample)

boiled rays using a 5 points scale) were determined as described in the previous paper [1].

\section{Procedure}

The ray wings were divided into three batches. A first batch was washed by dipping for $30 \mathrm{~s}$ in tap water, iced and stored at $0 \mathrm{C}$. The second and a third batches were soaked for $5 \mathrm{~min}$ in a $12 \%$ TPP solution ( $\mathrm{pH} 8.15$ ) and in a $0.5 \%$ citric acid solution ( $\mathrm{pH} 3.00$ ) in tap water, respectively, maintained at $5 \mathrm{C}$ before being iced and stored at $0^{2} \mathrm{C}$.- Screening tests showed that higher concentrations of TTP and citric acid influenced the appearance. texture and taste of the fish.-At five time intervals (Fig. 1-3), five wings from each batch were taken for objective and organoleptic tests, which were carried out on pooled samples. From the ninth day on, organoleptic tests were performed daily.--The experiments were repeated fixe times during the period November-January.

\section{Results and Discussion}

Dipping ray wings in TPP and citric acid solutions gave an average weight increase of 3.6 and $2.7 \%$, respectively. After storage for eight days the TPP batch had again lost $3.1 \%$, which is quite normal for such a treatment. The fish that had been soaked in a citric acid solution, on the other hand, had lost $8.2 \%$, indicating that the decrease in $\mathrm{pH}$ (see later) had diminished the water-holding capacity of the muscle by shifting the proteins closer to their isoelectric point. However this did not influence the quality of the fish significantly.

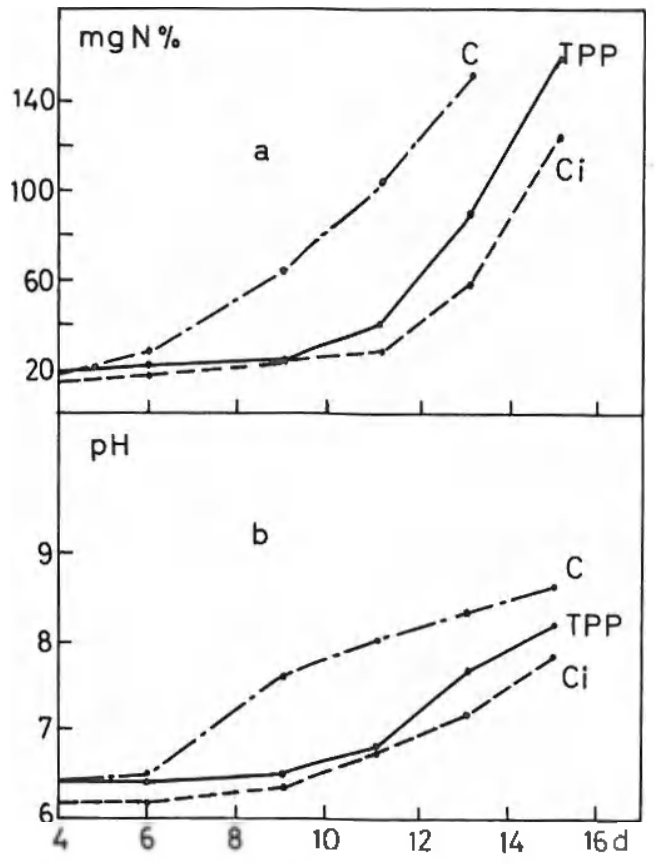

Fig. 2a and b. Frolution of ammonia a and pH b (see Fig. 1 for (urther details)

The average results of the quality tests of the five experiments are reported graphically in Figure 1. Dipping the rays in TPP or citric acid solutions markedly changed the spoilage pattern as measured by the different subjective and objective methods. Organoleptic score 3 (borderline of acceptability) on raw and steamed untreated fish was reached after 10 $( \pm 1)$ days. With TPP and citric acid treated rays, shelf life was prolonged by 2 and $3( \pm 1)$ days respectively. The confirmatory boiling test in water containing acetic acid and salt was positive after 10,12 and 13 $( \pm 1)$ days for the control, TPP and citric acid samples respectively.

Treatment with TPP improved the appearance of the ray wings, intensifying the pinkish-red colour of the skinned fish in most cases. Citric acid on the other hand had a slight bleaching action. In some instances some yellowish discoloration was noted at the fringes of the wings. The same discoloration however occirs quickly also when untreated ray wings are exposed to air, e.g during retail sales. As citric acid treated rays exuded somewhat more fluid during storage, texture was slightly dryer after cooking. The taste panel however did nor judge this to be a serious drawback.

The evolution of ammonia and $\mathrm{pH}$ in the ray wings confirmed the organoleptic judgments (Fig. 1). There was a marked difference between the curves of the three batches, indicating that TPP and citric acid 
treatment slowed down the progress of spoilage as measurcd by the content of ammonia and $\mathrm{pH}$.

The differing influence of TPP and citric acid dips or the initial $\mathrm{pH}$ should be strcssed, taking into account the high buffering capacity of fish muscle. Although TPP is rather alkaline it had little effect on tissue $\mathrm{pH}$ in the concentration used, which confirmed observations made earlier by other authors $[13,14]$ Citric acid on the other hand lowered the $\mathrm{pH}$ markedly. Measurements made on 25 wings showed this decrease to be $0.28 \mathrm{pH}$-unit on average (standard deviation 0.081 ). The lower bacterial counts noted up to the ninth day of storage of the citric acid treated rays were probably due to this initial decrease in $\mathrm{pH}$ From the ninth day on however bacterial counts were similar to the control sample; this was no longer in agreement with the lower content of ammonia and the lower $\mathrm{pH}$ (Fig. 2). The lower $\mathrm{pH}$ during the first days of storage possibly also inhibited urease activity partially but on the other hand it should be kept in mind that chelating agents (such as citric acid) protect the urease SH-groups by binding heary metals [15]. Citric acid can also bind ammonia directly. An estimated uptake of $10-15 \mathrm{mg}$ per $100 \mathrm{~g}$ of fish can neutralize only 2-3 $\mathrm{mg}$ ammonia- $\mathrm{N}$, which is almost negligible.

With TPP no significant difference in total bacteria was observed. TPP however possibly had an influence on the urease activity itself. It has indeed been suggested that complexes formed by alkali cations with phosphate ions inhibit urease [16]. In this respect it should be noted that TPP is readily hydrolyzed to orthophosphate during storage of fish by enzymic action in the presence of myosin [17] (Fig. 3).

Additional experiments were carried out in order to evaluate the influence of longer dipping times in TPP and citric acid solutions. With TPP "metallic" flavours were detected when the fish remained longer than $10 \mathrm{~min}$ in the solution. No significant differences in organoleptic scores, ammonia and $\mathrm{pH}$ were found between 5 and $15 \mathrm{~min}$ in citric acid solution. With longer soaking times, a brownish discoloration appeared and the fish acquired a "marinated" look. Weight losses were also unacceptahle (more than $10 \%$ ). Hence, it could be concluded that a 5 min dip was sufficient.

To conclude, the use of both TPP and citric acid could be of value to the trade $i$ those cases where an extension of shelf-life is desirable. With TPP dips a shelf-iffe exterision of about 2 days can be expected, together with an improved appearance of the ray wings and an elimination of weight losses. With citric acid a 3 day extension of storage life can be assured but this treatment has a slight bleaching effect and caused a

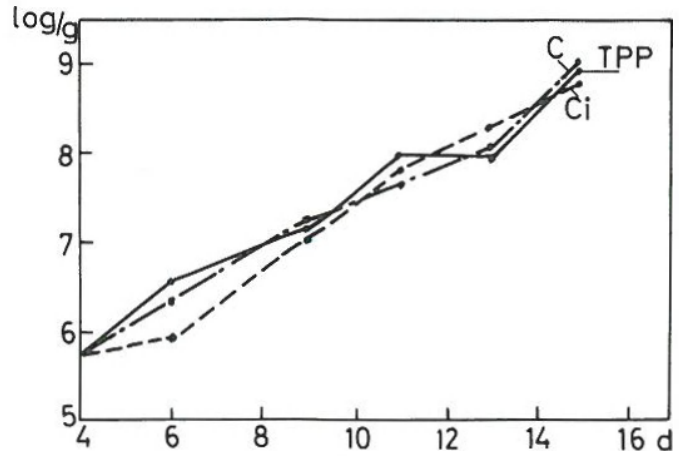

Fig. 3. Exolution of total bacterial counts (see Fig. 1 for further details)

loss of about $5 \%$ of the original weight. It could be recommended however in those instances where the use of polyphosphates is restricted by the Health Authorities.

Finally it should be stressed that the dip treatments were carried out on rays that were $4( \pm 1)$ days old. A different and probably greater extension of shelf-life is possible when dips are applied to freshly caught fish, when urease producing bacteria are present in much lower numbers.

\section{References}

1. Vyncke, W.: J. Food Technol. 13,37 (1978)

2. Spencer, J., Smith.L. : Poultry Sci. 41, 1685 (1962)

3. Elliot, R., Straka, R., Garibaldi,J.: Appl. Microbiol. 12, 517 (1964)

4. Levin, Ix : .l. Milk Food Technol 30, 277 (1967)

5. Doesburg. I. Lamprecht, E., Elliot1, M.: Fishing Industry. Capetown'South Africa: Research Institute 1967. Annual Report p. 56

6. Dyer, W.: 'Freezing and Irradiation of Fish', p. 167, Ed. R. Kreuzer. London: Fishing News (Books) Lrd 1969

7. Glandorl, K.: Allg. Fischwirtschaftsz. 1 2, 133 (1959)

8. Furia, T. (Ed.): Handbook of Food Additives, p. 263 Cleveland Ohio, USA: The Chemical Rubber Co. 1968

9. Warfel, H.. Clague, J.: U.S. Fish Wildl. Serv., Res, Rep. 15 (1950)

10. Beraquet. N.. Okada. M.. Ferriera, V., Menezes.H. : Coletaneo do Instituto de Tecnologia de Alimentos 6, 37 (1975)

11. Nadeau, A.: Progr. Rep. Atlant. Coast Stat. (Fish. Res. Board Canada) 24, 3 (1939)

12. Tarr,H : Prog. Rep. Pacif. Coast Slat. (Fish. Res. Board Canada) 43, $10(1940)$

13. Ohta, F. Nichimoto. J. : Mem. Fac. Fish. Kagoshima Univ. 12, 14 (1963)

14. Boyd, 3., Southcott, B.: 3. Fish. Res. Board Canada 22, 53 (1965)

15. Pinter, T., Tashorski,D., Karas, V. : Biochem. Z. 325, 239 (1954)

16. Kistiakowsky, G., Mangelsdorf, P. Jr., Rosenberg, A., Shaw, W. : J. Am. Chem. Soc, 74, 5015 (1952)

17. Sutton, A. : I. Food Technol. 8, 185 (1973)

Received March 2.1978 